\title{
Effect of Doctor's Personality, Job Characteristic, Payment Method, Facility, on Performance and Quality of Doctor Service
}

\author{
Heni Hastuti 1,2), Didik Tamtomo 2), Endang Sutisna Sulaeman 2) \\ 1)Masters Program in Public Health, Universitas Sebelas Maret, Surakarta \\ 2)Faculty of Medicine, Universitas Sebelas Maret, Surakarta
}

\begin{abstract}
Background: Doctors generally do not work permanently at hospitals. Doctors are expected to deliver quality medical service at the hospitals. However, hospital often find it difficult to exercise effective managerial control over the quality of medical services. This study aimed to investigate the effect of doctor's personality, job characteristic, payment method, facility, performance and quality of doctor service.

Subjects and Method: This was an analytic observational study using cross-sectional design. The study was carried out at Dr. Moewardi Hospital and PKU Muhammadiyah Hospital, Surakarta from March to May 2017. A sample 182 study subjects consisting of 26 doctors, 26 nurses, and 130 patients, were selected for this study by simple random sampling. The dependent variable was quality of doctor service. The independent variables were doctor's personality (extrovert vs. introvert), doctor's carefulness, proactive attitude, self-efficacy, autonomy, performance feedback, supervisor support, payment method, work site (private vs. public), and performance. Questionnaire was used to collect data. Path analysis was employed to analyze the data.

Results: Good quality of doctor service was directly affected by good performance $(b=0.64$, $\mathrm{SE}=0.11, \mathrm{p}<0.001)$, private work site $(\mathrm{b}=2.85, \mathrm{SE}=0.66, \mathrm{p}<0.001)$, and strong self-efficacy $(\mathrm{b}=$ $0.21, \mathrm{SE}=0.07, \mathrm{p}=0.006)$. Good work performance was affected by extrovert personality $(\mathrm{b}=0.08$, $\mathrm{SE}=0.06, \mathrm{p}=0.186)$, careful attitude $(\mathrm{b}=0.30 ; \mathrm{SE}=0.09 ; \mathrm{p}=0.001)$, proactive personality $(\mathrm{b}=-0.17$; $\mathrm{SE}=0.05 ; \mathrm{p}=0.001)$, strong self-efficacy $(b=0.27 ; \mathrm{SE}=0.07 ; \mathrm{p}<0.001)$, autonomy $(b=0.16 ; \mathrm{SE}=0.06$; $\mathrm{p}=0.015)$, performance feedback $(\mathrm{b}=0.43 ; \mathrm{SE}=0.13, \mathrm{p}<0.001)$, supervisor support $(\mathrm{b}=0.14, \mathrm{SE}=$ 0.06, $\mathrm{p}=0.018$ ), payment method (INA CBGs) $(\mathrm{b}=-2.29 ; \mathrm{SE}=0.66 ; \mathrm{p}<0.001)$, and private work site $(b=-0.26, \mathrm{SE}=0.68, \mathrm{p}=0.696)$.
\end{abstract}

Conclusion: Good quality of doctor service is directly affected by good performance, private work site, and strong self-efficacy.

Keywords: quality, doctor's service, performance, path analysis

\section{Correspondence:}

Heni Hastuti. Masters Program in Public Health, Universitas Sebelas Maret. Jl. Ir. Sutami 36A, Surakarta 57126, Central Java. Email: henihastuti.1988@gmail.com Mobile: +6281904534310.

\section{BACKGROUND}

The healthcare system in Indonesia is progressing and expanding rapidly. It occurs due to various factors, such as the increase of access to technology, the increase of disposable income, an increasing number of skilled medical professionals, a focus on strengthening the health system by central and local governments, and Indonesian people who want to get better health services (Frost, 2015). A country needs to formulate ways to improve the quality of health services in realizing and maintaining healthy society (Michael, 2006).

Quality is the most dominant part of health services. People will always look for quality services including health services. Everyone has the right to get quality health services. The result of higher quality health 
services make patients, doctors, employees, and health service organizations feel satisfied (Mosadeghrad, 2012).

Individual performance is conceptualized and operationalized differently in different disciplines (Koopman, 2011). A key in strengthening health care systems is by setting standards and measures of the quality and efficiency of doctors and hospitals. This measurement has great potential to improve performance between doctors, hospital staffs, and other employees (Jon, 2008). The performance measurement systems and the results should be measured based on evidence-based standards in service practices (Jon, 2008).

The report from Frost and Sullivan Health Care Outlook (2015) concluded that Indonesia's economic condition in the health sector in 2015 was highly positive. GDP (Gross Domestic Product) growth by $4.79 \%$, low inflation by $2.4 \%$, and falling fuel prices, created public optimism and increased spending on health services.

A total number of hospitals in Indonesia in 2015 was 2,488 divided into 1,593 Government Hospitals, 1,341 General Hospitals, and 252 Special Hospitals. Meanwhile, a total number of Private Hospitals was 895 which were divided into $608 \mathrm{Ge}-$ neral Hospitals and 287 Special Hospitals. A total number of government and private hospitals showed an increase in the period of 2013-2014 by 178 hospitals and slightly decreased in 2015 (Ministry of Health, 2016).

The current health care systems in hospitals are much better to the society because it is important to evaluate the quality of health services provided (Wagner et al., 2014). The health sector is currently seen as a business organization. Therefore, health services are the fastest growing services in developed and developing countries (Pai and Chary, 2016).
Dr. Moewardi Hospital, Surakarta, is a hospital owned by the Central Java province of type A which has achieved many achievements and has passed plenary accreditation from KARS (Hospital Accreditation Commission) in 2012 and currently preparing JCI (Joint Commission International) Accreditation in 2015. PKU Muhammadiyah Hospital, Surakarta, is a class B hospital owned by Persyarikatan Muhammadiyah Foundation and has also passed plenary accreditation from KARS. KARS accreditation is the Hospital Accreditation Commission which aims to improve the quality of hospital services through accreditation (Hospital Accreditation Commission, 2015).

Based on the background above, the researchers are interested in conducting study related to the effect of doctor's personality which include extrovert personality, carefulness personality (conscientiousness), proactive personality, and self-efficacy. In addition, the job characteristics are autonomy, performance feedback, hospital supervisor support; payment method by providers and workplace institutions on the performance and the quality of doctor service.

\section{SUBJECTS AND METHOD}

\section{Design of the Study}

This study used an analytic observational study using cross-sectional design. This study conducted from March to May 2017 at Dr. Moewardi Hospital and PKU Muhammadiyah Hospital, Surakarta.

\section{Population and Sampling}

The population of the study was doctors, nurses in hospitals, and patients served by these doctors. The subjects of this study were doctors, nurses, patients at Dr Moewardi Hospital and PKU Muhammadiyah Hospital, Surakarta. This study used random sampling for taking subjects of the study. This technique was a scheme of sam- 
pling which provided the same opportunity to be taken in each population studied. A total number of the subjects of this study were 182 people: 13 doctors at Dr. Moewardi Hospital, 13 doctors at PKU Muhammadiyah Hospital, 26 nurses, and 130 patients served by these doctors.

\section{Study Variables}

The dependent variable was quality of doctor service. The independent variables were doctor performance, doctor's extrovert personality, doctor's carefulness personality, doctor's proactive personality, doctor's selfefficacy, doctor autonomy, doctor performance feedback, hospital supervisor support, payment method, work site.

\section{Operational Definition of Variables}

The operational definition of a doctor's extrovert personality was the nature of openness which built a person's personality. The signs were easy to socialize, talkative, and strict. As a result, the individual became more confident in working. They would be more involved and had better performance.

The doctor's carefulness personality was a nature of personality which careful and watchful which generally, it was hardworking and reliable. A careful individual had a strong sense of responsibility; as a result, the employees became more involved in their tasks.

Doctor's proactive personality was those who identified opportunities, showed initiative, took action, and survived until significant changes occured. Doctor's selfefficacy was an individual's belief on his/her ability in performing tasks or actions needed to achieve certain results.

Doctor autonomy was the belief and ability that individual was able to think logically and able to make his/her own decisions, to govern themselves, to take care of themselves, or to manage his/her own interests.

Doctor performance feedback was a process in which some output were returned to the input section or gave it back. Hospital supervisor support was an extent to which superiors behave in supporting and strengthening employees by optimizing the use of knowledge, skills and attitudes of employees obtained in job training.

Provider payment method was a payment method used by service providers or service owners to service providers or employees. Work site was an area where doctors worked.

Doctor performance was an overall result or success level of a person during a certain period in carrying out tasks according to predetermined and agreed criteria. A quality of doctor service was a dynamic condition which affected products, services, people, processes, and environments that meet or exceed expectations.

\section{Study Instrument}

The instrument of this study used questionnaires. The questionnaire has been tested for validity and reliability. The results are shown in Table 1 . The provider payment method was measured by o category for fee for service and 1 category for INA CBGs. Work site was measured by o category for government hospital (Dr. Moewardi Hospital, Surakarta) and 1 category for private hospital (PKU Muhammadiyah Hospital, Surakarta).

A questionnaire consisted of favorable statements (statements which contained negative things and support the poor quality of doctor service) and unfavorable statements (statements which contained positive things and support the good quality of doctor service). 
The Journal of Health Policy and Management (2017), 2(1): 42-57

https://doi.org/10.26911/thejhpm.2017.02.01.04

Table 1. The result of reliability test

\begin{tabular}{lcc}
\hline \multicolumn{1}{c}{ Variable } & Item Correlation (r) & Total Alpha Cronbach \\
\hline Doctor's extrovert personality & $\geq 0.25$ & 0.80 \\
Doctor's carefulness personality & $\geq 0.26$ & 0.76 \\
Doctor's proactive personality & $\geq 0.33$ & 0.89 \\
Doctor's self-efficacy & $\geq 0.40$ & 0.85 \\
Doctor autonomy & $\geq 0.32$ & 0.88 \\
Doctor performance feedback & $\geq 0.51$ & 0.74 \\
Hospital supervisor support & $\geq 0.47$ & 0.84 \\
Doctor performance & $\geq 0.57$ & 0.78 \\
Quality of doctor service & $\geq 0.35$ & 0.79 \\
\hline
\end{tabular}

\section{Data Analysis}

This study used univariate, bivariate, and multivariate analysis. Path analysis was analyzed using AMOS. The steps for analyzing data using path analysis were as follows:
a. model specifications,
b. model identification,
c. model fit,
d. parameter estimation,
e. respecification of the model.

\begin{tabular}{l} 
RESULTS \\
\hline 1. Sample Characteristics
\end{tabular}

\section{Sample Characteristics}

The characteristics of subjects of the study are shown in Table 2 and 3. The results of the characteristics of subjects of the study of the doctor showed that the doctors who served in the polyclinic were mostly female, which were 19 doctors (73\%). There were 13 doctors based on the characteristics of public and private hospitals with the same di- vision. There were 8 parts such as general practitioner, dentist, ophthalmologist, internist, pediatrician, dermatologist, surgeon, neurosurgeon with mostly on the eyes, which were 7 doctors ( $26.9 \%$ ).

The results of the characteristics of nurses as the subject of the study showed that the nurses who served in the polyclinic were mostly female, which were 25 doctors (96.1\%). There were 13 doctors based on the characteristics of public and private hospitals with the same division.

The results of the characteristics of patients as the subject of the study showed that the patients who were served in the polyclinic of PKU Muhammadiyah and Dr. Moewardi Hospitals, Surakarta, were mostly aged between 40-60 years (33.8\%). Most patients were female, which were 83 people (63.8\%). Most of them worked as housewives, which were 29 people (22.3\%).

Table 2. The characteristics of doctors as the subject of the study

\begin{tabular}{llcc}
\hline The Characteristics of Subject & Criteria & Frequency & (\%) \\
\hline Gender & Male & 7 & 27 \\
Work Site & Female & 19 & 73 \\
Type of Polyclinic & Public & 13 & 50 \\
& Private & 13 & 50 \\
& General & 6 & 23 \\
& Dental & 6 & 23 \\
& Eye & 7 & 26.9 \\
& Skin & 2 & 7.6 \\
& Surgical & 1 & 3.8 \\
& Child & 1 & 3.8 \\
& Internal Medicine & 1 & 3.8 \\
& Nerve & 2 & 7.6 \\
\hline
\end{tabular}




\section{Univariate Analysis}

The results of the descriptive of variable of the study were shown in Table 4 . The results of the analysis were shown in minimum, maximum, mean, and SD data.

\section{Bivariate Analysis}

Table 5 shows that the result of data analysis on the variables of doctor's extrovert personality, doctor's carefulness personality, doctor's proactive personality, doctor's self-efficacy, doctor autonomy, doctor performance feedback, hospital supervisor support, provider payment method, and work site on doctor performance was $\mathrm{p}<0.001$.

Table 6 shows that the result of data analysis on variables of doctor's self-efficacy, work site, and doctor performance on quality of doctor service was $\mathrm{p}<0.001$.

Table 3. The characteristics of patients as the subject of the study

\begin{tabular}{llcc}
\hline Characteristics & Criteria & Frequency & (\%) \\
\hline Patient Age & < 20 Years & 12 & 9.2 \\
& 20-<40 Years & 33 & 25.3 \\
& 240-60 Years & 44 & 33.8 \\
Zender & Co Years & 41 & 31.4 \\
& Male & 47 & 36.2 \\
Occupation & Female & 83 & 63.8 \\
& Unemployed & 6 & 4.6 \\
& Student/College Student & 23 & 17.6 \\
& Civil Servant & 12 & 9.2 \\
& Private Employee & 26 & 20 \\
& Entrepreneur & 9 & 6.9 \\
& Farmer & 4 & 3 \\
& Labor & 3 & 2.3 \\
& Housewife & 29 & 22.3 \\
& Retired Civil Servant/Pensioner & 18 & 13.8 \\
\hline
\end{tabular}

Table 4. The descriptive of variable of the study

\begin{tabular}{lccrl}
\hline Variable & Minimum & Maximum & Mean & SD \\
\hline Doctor's extrovert personality & 9 & 22 & 16.81 & 4.34 \\
Doctor's carefulness personality & 11 & 24 & 19.42 & 2.85 \\
Doctor's proactive personality & 9 & 24 & 17.65 & 4.85 \\
Doctor's self-efficacy & 13 & 30 & 22.85 & 5.11 \\
Doctor autonomy & 10 & 24 & 20.27 & 4.11 \\
Doctor performance feedback & 4 & 9 & 6.54 & 1.85 \\
Hospital supervisor support & 7 & 21 & 15.08 & 4.40 \\
Doctor performance & 6 & 15 & 11.54 & 3.78 \\
Quality of doctor service & 9 & 26 & 17.90 & 5.33 \\
\hline
\end{tabular}

Table 5. The bivariate analysis of independent variables on doctor performance

\begin{tabular}{lcc}
\hline Variable & $\mathbf{r}$ & $\mathbf{p}$ \\
\hline Doctor's extrovert personality & 0.51 & $<0.001$ \\
Doctor's carefulness personality & 0.51 & $<0.001$ \\
Doctor's proactive personality & 0.34 & $<0.001$ \\
Doctor's self-efficacy & 0.72 & $<0.001$ \\
Doctor autonomy & 0.34 & $<0.001$ \\
Doctor performance feedback & 0.45 & $<0.001$ \\
Hospital supervisor support & 0.59 & $<0.001$ \\
Provider payment method & 0.51 & $<0.001$ \\
Work site & 0.54 & $<0.001$ \\
\hline
\end{tabular}


The Journal of Health Policy and Management (2017), 2(1): 42-57

https://doi.org/10.26911/thejhpm.2017.02.01.04

Table 6. The bivariate analysis of independent variables on quality of doctor service

\begin{tabular}{lcc}
\hline Variable & $\mathbf{R}$ & $\mathbf{p}$ \\
\hline Doctor's self-efficacy & 0.67 & $<0.001$ \\
Work site & 0.62 & $<0.001$ \\
Doctor performance & 0.75 & $<0.001$ \\
\hline
\end{tabular}

\section{Multivariate analysis}

Figure 1 shows that the structural model has been estimated using SPSS Amos. Indicators which showed the suitability of the model in Figure 1 were CMIN (Norm Chi Square $)=4.37 ; \quad \mathrm{p}=0.736 \quad(>0.05) ; \mathrm{GFI}$ (Goodness of Fit Index) $=0.99(\geq 0.90)$; NFI (Normed Fit Index) $=0.99 \quad(\geq 0.90)$; CFI (Comparative Fit Index)=1.00 $(\geq 0.90)$; RSMEA (Root Mean Square Error of Approximation $)<0.001(<0.08)$. These results indicated that the model met the criteria and empirical data; as a result, path analysis can be conducted.
Based on Table 7, it shows that the quality of doctor services was affected by the performance of doctors, work site (private), doctor's self-efficacy. Every increase in one unit of doctor performance would increase the quality of doctor service by 0.64 units. Every increase in one unit of work site (private) would increase the quality of doctor service by 2.85 units. Every increase in one unit of doctor's self-efficacy would increase the quality of doctor service by 0.21 units.

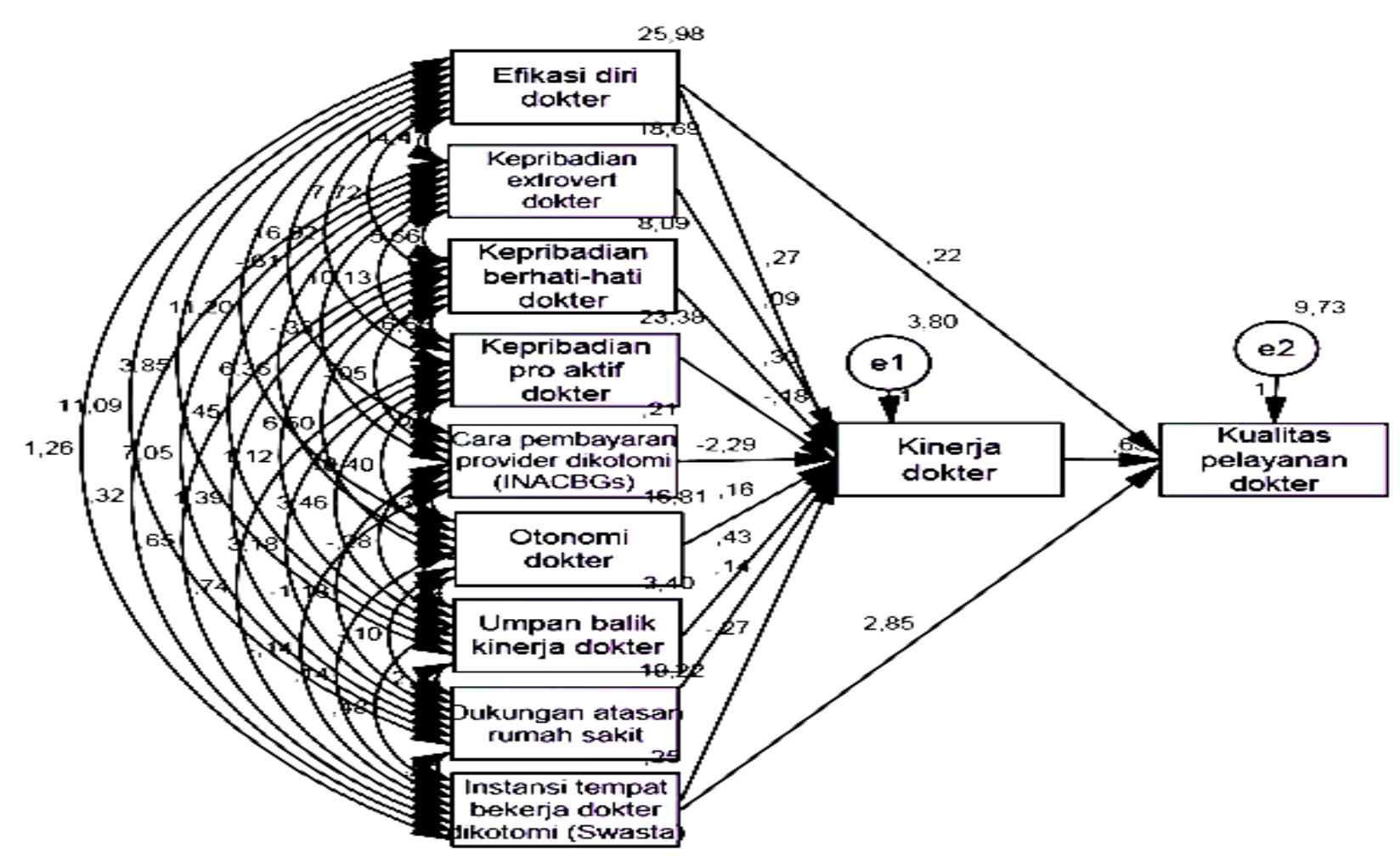

Figure 1. The structural model with unstandardized estimates 
Table 7. The result of Path Analysis of factors which affect quality of doctor service

\begin{tabular}{|c|c|c|c|c|c|c|}
\hline Endogenous Variable & & Exogenous Variable & $\mathbf{b}^{*}$ & SE & $\mathbf{p}$ & $\boldsymbol{\beta}^{* *}$ \\
\hline Direct Effect & & & & & & \\
\hline Quality of doctor service & $\leftarrow$ & Doctor performance & 0.64 & 0.11 & $<0.001$ & 0.46 \\
\hline Quality of doctor service & $\leftarrow$ & Work site & 2.85 & 0.66 & $<0.001$ & 0.26 \\
\hline Quality of doctor service & $\leftarrow$ & Doctor's self-efficacy & 0.21 & 0.07 & 0.006 & 0.20 \\
\hline IndirectEffect & & & & & & \\
\hline Doctor performance & $\leftarrow$ & $\begin{array}{l}\text { Doctor performance } \\
\text { feedback }\end{array}$ & 0.43 & 0.13 & $<0.001$ & 0.21 \\
\hline Doctor performance & $\leftarrow$ & Provider payment method & -2.29 & 0.66 & $<0.001$ & -0.28 \\
\hline Doctor performance & $\leftarrow$ & $\begin{array}{l}\text { Hospital supervisor } \\
\text { support }\end{array}$ & 0.14 & 0.06 & 0.018 & 0.16 \\
\hline Doctor performance & $\leftarrow$ & $\begin{array}{l}\text { Doctor's proactive } \\
\text { personality }\end{array}$ & -0.17 & 0.05 & 0.001 & -0.22 \\
\hline Doctor performance & & $\begin{array}{l}\text { Doctor's carefulness } \\
\text { personality }\end{array}$ & 0.30 & 0.09 & 0.001 & 0.22 \\
\hline Doctor performance & $\leftarrow$ & Doctor autonomy & 0.16 & 0.06 & 0.015 & 0.17 \\
\hline Doctor performance & $\leftarrow$ & Work site & -0.26 & 0.68 & 0.696 & -0.03 \\
\hline Doctor performance & & $\begin{array}{l}\text { Doctor's extrovert } \\
\text { personality }\end{array}$ & 0.08 & 0.06 & 0.186 & 0.09 \\
\hline $\begin{array}{l}\text { Doctor performance } \\
\text { Fit Model }\end{array}$ & $\leftarrow$ & Doctor's self-efficacy & 0.27 & 0.07 & $<0.001$ & 0.36 \\
\hline CMIN $=4.369$ with & $=0$. & $736(>0.05)$ & & & & \\
\hline$=0.99$ & $(>$ & $0.90)$ & 1.00 & $(>0$ & 90 ) & \\
\hline$=0.99$ & $(>$ & RMSEA & 0.001 & $(<0$ & 80 ) & \\
\hline
\end{tabular}

Doctor performance was affected by doctor performance feedback, provider payment method (INA CBGs), hospital supervisor support, doctor's proactive personality, doctor's carefulness personality, doctor autonomy, work site (private), doctor's extrovert personality, doctor's self-efficacy. Every increase in one unit of doctor performance feedback would increase the doctor performance by 0.43 units. Every increase in one unit of provider payment method (INA CBGs) would decrease the doctor performance by 2.29 units .

Every increase in one unit of hospital supervisor support would increase the doctor performance by 0.17 units. Every increase in one unit of doctor's proactive personality would decrease the doctor performance by 0.17 units. Every increase in one unit of doctor's carefulness personality would increase the doctor performance by 0.30 units.

Every increase in one unit of doctor autonomy would increase the doctor performance by 0.16 units. Every increase in one unit of work site (private) would decrease the doctor performance by 0.26 units, but statistically non-significant. Every increase in one unit of doctor's extrovert personality would increase the doctor performance by 0.08 units, but statistically non-significant. Every increase in one unit of doctor's self-efficacy would increase the doctor performance by 0.27 units.

\section{DISCUSSION}

\section{The correlation between doctor performance and quality of doctor service}

This study showed that there was a correlation between doctor performance and qua- 
lity of doctor service. The high doctor performance gives high score on quality of service compared to the low doctor performance. According to Bruce et al., (2007) and Shaw (2003), the doctor performance refers to medical professionalism. In the document of "Medical Professionalism in the New Millennium: Doctors Charter" (created and adopted by many medical specialties both in the United States and in the world), it states that "professionalism is the basis of a doctors contract with community." The document contains three basic principles and ten professional responsibilities that describe contracts with the community.

The doctor performance in a hospital can be defined according to the achievement of specified targets, both clinical and administrative. Targets are associated with the initial functions of the hospital, such as diagnosis, care and rehabilitation, and teaching and study. The measure of doctor performance will affect the performance of the Hospital. Factors which affect doctor performance are knowledge, skills, motivation, and roles which can improve quality of doctor service.

\section{The correlation between work site (private) and quality of doctor ser- vice}

This study showed that there was a correlation between work site and quality of doctor service. Doctor who work in private work site gives high score on quality of service compared to the public work site. The result of this study is supported by study conducted by Khattab (2011) in Jordan, Irfan (2011) in Pakistan, Sarwar (2014) in Malaysia, Yongyuth (2011) in Thailand, and Basu et al., (2012) about hospitals in underdeveloped and developing countries. They state that quality of doctor service offered in private hospitals is higher than public hospitals.
Private hospitals are considered to be more successful than public hospitals because they focus on the patients' needs and desires. Therefore, doctors are able to provide quality services than doctors who work in public hospitals. It occurs because they have to complete their obligations as lecturers, such as three pillars of higher education (teaching, research, and service); as a result, they cannot only focus on the patients.

\section{The correlation between doctor's self-efficacy and quality of doctor service}

This study showed that there was a correlation between doctor's self-efficacy and quality of doctor service. A doctor with strong self-efficacy score gives high score on quality of service. The result of this study is supported by a study conducted by Prahbu et al., (2008) cited in Reaves (2015) which state that self-efficacy has motivational component, so that an individual who has confidence in their work (strong self-efficacy), has more motivation to do their work and feel more interested because they are more involved.

A doctor with strong self-efficacy will feel confident and motivated to be able to care for patients until they are cured and able to build trust in patients. According to the communication aspects between doctor and patient, doctors are required to be confident and not hesitate in giving service. According to Sunarto (2005), communication affects quality of service. The better communication is carried out, the better the quality of service. It occurs because communication can provide clear information.

\section{The correlation between doctor's extrovert personality and doctor performance}

This study showed that there was a correlation between doctor's extrovert personality 
and doctor performance. A doctor with high extrovert personality gives high score on doctor performance, thus providing better quality of doctor service. The result of this study is supported by a study conducted by Langelaan et al., (2007) which states that extrovert personality will find more energy from the social aspects of their work, which refers to be more involved and have better performance. Furthermore, the trust component of extrovert personality will cause individual becomes more confident in their work. From this belief they will be more involved and have better performance.

A doctor who has extrovert personality in social aspects can put themselves in the right situation because the doctor is easier to express feelings with words. In addition, it is easier to build feeling and good communication which is connected with patients. Therefore, there is two-way communication between doctor and patient. Good communication will make the patient believe in the doctor, so that the patient will feel safe and believe that the doctor will seriously care for the patient. One of the reasons is the patient's assessment of the quality of doctor service that is not as expected, such as the communication aspect; the message becomes unclear because the expressions are not understood by the patient or the communication is not optimal.

This is supported by Sunarto (2005) which states that communication affects quality of service. The higher/better the communication is carried out, the higher/better the quality of service, because communication can provide clarity of information. In addition, goals will be more easily achieved.

\section{The correlation between doctor's carefulness personality and doctor performance}

This study showed that there was a correlation between doctor's carefulness persona- lity and doctor performance. A doctor with high carefulness personality improves the doctor performance, so that it affects the quality of doctor service. According to Christian et al. (2011), carefulness personality can predict employee participation in improving performance. Individual who is careful has a high responsibility, so that employees are more involved in their tasks. Aspect of achievement is related to performance because people have goals and motivations. Aspect of carefulness personality competence also explains why there it is related to performance. The individual who understand their work well tend to be more involved in their work.

A doctor must have a carefulness personality because it concerns to people's lives, so all actions must be carried out carefully, thoroughly and precisely. A doctor who has high carefulness personality is usually more responsible, so that the doctor performance increases and the medical errors decrease. As a result, malpractice does not occur.

\section{The correlation between doctor's proactive personality and doctor performance}

This study showed that there was a correlation between doctor's proactive personality and quality of doctor service. A doctor with high proactive personality gives low score on doctor performance and affects quality of doctor service. According to Reaves (2015), proactive personality is considered as predictor of employee participation in performance improvement. Doctor's proactive personality is not only taking the initiative, but also looking for opportunities to learn and involving in learning activities.

A doctor with proactive personality refers to the participation of doctors outside the activities of serving patients. A doctor has to increase their knowledge through seminars and workshops because medical sci- 
The Journal of Health Policy and Management (2017), 2(1): 42-57

https://doi.org/10.26911/thejhpm.2017.02.01.04

ence develops continuously and it is needed for lifelong education. A doctor not only has a role as functional doctor but also as structural doctor. Other tasks can take time, so that the doctor only has short time to meet patients. Meanwhile, there are many patients who need to be served, so they do not seem to give maximum service. In addition, the doctor schedules inside and outside the hospital make the doctor is not able to come on time.

\section{The correlation between doctor's self-efficacy and doctor perfor- mance}

This study showed that there was a correlation between doctor's self-efficacy and quality of doctor service. A doctor with strong self-efficacy gives high score on doctor performance and affects quality of doctor service. The result of this study is supported by Bakker et al., (2007) which state that selfefficacy can be a motivator and can have a positive effect on performance. Some studies show that self-efficacy has a positive effect on performance as a personal resource. Self-efficacy is a part of psychological capital and a personal resource which facilitates employee participation in improving performance. According to Prahbu et al., (2008) cited in Reaves (2015) theorize that self-efficacy has a motivation component, so that an individual who has confidence in their work (strong self-efficacy) has more motivation to do their work and feel more interested (more involved).

A doctor with strong self-efficacy is able to build trust in patients. According to the communication aspects between doctor and patient, doctors are required to be confident and not hesitate in giving service. The higher/better the communication is carried out, the higher/better the quality of service, because communication can provide clarity of information. In addition, goals will be more easily achieved.

\section{The correlation between doctor au- tonomy and doctor performance}

This study showed that there was a correlation between doctor autonomy and doctor performance. A doctor with high autonomy gives high score on doctor performance and affects quality of doctor service. The result of this study is supported by Bakker et al., (2007) and Salanova et al. (2010) which state that autonomy is an example of a level of duty on intrinsic resources that can motivate individuals and increase the potential for development and learning.

Theory of self-determination states that autonomy aims to control and fulfill basic human needs. A study on the self-determination theory also shows that a doctor who is motivated at work site, will gives their attention and efforts focused on their work. As a result, it leads to better performance. Attention also causes employees to be more persistent and more likely to consider alternative approaches, which create more creativity that illustrates the role of mediation between autonomy and performance (Shalley, 2008 in Reaves, 2015).

The profession of a doctor is closely related to ethical beneficence, non- maleficence, justice, and autonomy. Due to the nature of autonomy, doctor has a very strong authority in making decisions of diagnosis, scheduling, and doing therapy which is in accordance with evidence based medicine

\section{The correlation between doctor performance feedback and doctor performance}

This study showed that there was an indirect correlation which was positive and significant between doctor performance feedback and quality of doctor service. A doctor with high performance feedback gives high score on doctor performance and affects the quality of doctor service. The result of this study is supported by a study conducted by 
Bakker et al., (2007) and Reaves (2015) which state that feedback is a feature of a work environment that facilitates motivation. Motivation affects how far someone is willing to give energy to the tasks. Feedback is under the task level in work resources because it motivates individual to develop and learn from the feedback they get (Bakker et al, 2007). The self-determination theory shows that feedback meets basic human needs such as competence, thus improving performance (Reaves, 2015). This feedback system can secure widespread performance improvements.

A doctor can reflect on the previous performance achievements which are not good enough, so that it can be improved. The good achievement in the previous performance can be maintained, so that evaluations of performance are monitored.

\section{The correlation between hospi- tal supervisor support and doctor performance}

This study showed that there was a correlation between hospital supervisor support and doctor performance. A doctor who get hospital supervisor support can increase doctor performance and affects quality of doctor service. The result of this study is supported by a study conducted by Bakker et al., (2007) which state that supervisor support is at an interpersonal level in work resources. This work resource has a positive effect on performance improvement participation. According to Chughtai Adannd Buckley (2011) cited Reaves (2015), supervisor trust is positively related to employee engagement in improving performance.

Supervisor support affects employee participation and leads to higher performance. In improving quality of doctor service, an increase in knowledge and skills are needed. If the supervisor cares about the strengths of each individual doctor, such as giving training and school recommenda- tion, the doctor will be pleased and sincere in working.

\section{The correlation between provider payment method (INA CBGs) and doctor performance}

This study showed that there was a correlation between provider payment method (INA CBGs) and quality of doctor service. A doctor who is paid using INA CBG method gives low score on doctor performance compared to doctor who is paid using fee for service method, thus affecting quality of doctor service. The result of this study is supported by Gosden et al. (2000), Anastasia (2015), and Sisyani et al., (2016) which state that there is an effect on provider payment method. The researchers assume that doctor payment method can affect their clinical behavior. Payment system might be used to achieve policy objectives, so that it has impact on doctor performance.

One of the payment methods is the INA CBG method.The doctors are affected by their clinical behavior. They are previously paid with a fee for service, so that they can choose the best service. However, nowadays, they have to think about how the costs provided can be sufficient for patient care, so that the hospital does not feel any loss. Sometimes, the patient interest must be sacrified due to this method. Due to uncertainty over the issue of the adequacy of the claims of INA CBGs in covering health care costs, the hospital did not feel any loss with the INA CBGs claim system. In fact, the hospital feel benefited because there is nothing to worry about uncollectible service debts.

Problems often occur within the internal hospital itself. For example, doctor feels that INA CBGs claims are too small, while others feel that INA CBGs claims have been able to cover the cost of health services. Injustice is often complained of by 
health service providers, especially doctors. It starts from the unclear distribution of services provided by the hospital to the doctor which makes the doctors unmotivated in providing better services. As a result, the performance decreased because the amount of payment provided were unclear.

\section{The correlation between work site (private) and doctor performance}

This study showed that there was a correlation between work site (private) and doctor performance. A doctor who works in private work site give low score on doctor performance compared to doctor who works in public work site, thus affecting quality of doctor service. The result of this study is supported by Basu et al., (2012), and mehran et al., (2016) which state that the doctor's service system in private hospitals tends to be less in issuing data used to evaluate their performance. The orientation only serves patients without any other responsibilities beyond service to patients such as in public hospitals. Doctors also have to do three pillars of higher education because of the position as lecturers at the university, so that they have a greater risk than doctors in private hospitals who only serve patients and higher socio-economic groups. It can decrease their performance. The public sector tends to be less responsive to the patients and less responsive in handling raw materials. The private sector seems to have lower efficiency than the public sector. It is seen from higher drug costs and weak regulations which decrease the performance.

Based on the results of the study, quality of doctor service is affected by doctor performance, work site (private), and doctor's self-efficacy. Doctor performance is affected by doctor performance feedback, provider payment method (INA CBGs), hospital supervisor support, doctor's proac- tive personality, doctor's carefulness personality, doctor autonomy, work site (private), doctor's extrovert personality, and doctor's self-efficacy.

\section{REFERENCE}

Anastasia SA (2015). Besaran klaim INA CBGs, bisakah menutup biaya? pusat kebijakan manajemen kesehatan manajemen RS fk UGM (The magnitude of the INA CBGs claim, can cover the costs? Management Policy Center of RS FK UGM). Retrieved from https://manajemenrumahsakit.net/2015/o 7/besaran-klaim-ina-cbgs-bisakahmenutup-biaya/

Bakker AB, Demerouti E (2007). The job demands-resources model: State of the art. Journal of Managerial Psychology, 22: 309-328. Retrieved from https://pdfs.semanticscholar.org/535b/ dddb991b5ebe252e403ofd4c02c2368 egf14.pdf

Basu S, Andrews J, Kishore S, Panjabi R, Stuckler D (2012). Comparative performance of private and public healthcare systems in low-and middle-income countries: a systematic review. PLoS Med. 9(6): e1001244. doi: 10.1371/journal.pmed.1001244

Bruce E, Spivey, Walter, McDonald (2007). Physician practice measurement and quality improvement primer. United Healthcare Services, Inc.

Christian MS, Garza AS, Slaughter JE (2011). Work engagement: A quantitative review and test of its relations with task and contextual performance. Personnel Psychology, 64 (1): 89-136. Retrieved from https://arizona.pure.elsevier.com/en/publications/workengagement-a-quantitative-reviewand-test-of-its-relations-w 
Frost, Sullivan (2015). "We Accelerate Growth". 2015 APAC Healthcare Outlook:1-2. Retrieved from https://www.slideshare.net/FrostandSullivan/ap ac-healthcare-outlook-2012-2015what-comes-next

Gosden T, Forland F, Kristiansen IS, Sutton M, Lesse B, Giuffrida A, Sergison M, Pedersen L (2000). Payment: effects on the behaviour of primary care physicians. Cochrane Database Syst Rev 2000 (3):CDoo2215. doi 10.1002/14651858.CDoo2215

Irfan SM, Ijaz A (2011). Comparison ice quality between private and public hospitals: empirical evidences from Pakistan. Journal of Quality And Technology Management. 7(I):1- 22. Retrieved from http://pu.edu.pk/images/journal/iqtm/PDF-FILES/o1Comparison\%20of\%20Service\%20Qu ality\%2026-5-2011.pdf

Jon SC (2008). The relationship of hospitals and physicians. New Jersey Commission on Rationalizing Health Care Resources, 117-130.

Hospital Accreditation Commission (2015). Visi dan Misi (Vision and Mission). Retrieved from http://www. kars.or.id/?page_id=6o. Ministry of Health (2016).

Khattab AS, Aborumman A (2011). Healthcare service quality: comparing public and private hospitals in Jordan. International Business Management. 5(5): 247-254.

Langelaan S, Bakker AB, Van Doornen LJP, Schaifeli WB (2006). Burnout and work engagement: Do individual differences make a difference?. Personality and Individual Differences, 40: 521-532. Retrieved from https://dspace.library.uu.nl/bitstream/handle/187 4/19777/full.pdf?sequence $=10$
Mehran A, Seyed A, Roya R, Sayyid MA, Saeed A, Mahnaz A, Soheyla G (2016). Comparison quality of health services between public and private providers: The iranian people's perspective. Electron Physician. 8(9): 2935-2941. doi 10.19082/2935

Michael JM (2006). Quality of care. Johns Hopkins University:1-10.

Mosadeghrad AM (2012). A conceptual framework for quality of care. Mater Sociomed. 24(4): 251-261. doi 10.5455/msm.2012.24.251-261.

Pai YP, Chary ST (2016). Measuring patient-perceived hospital service quality: a conceptual framework. Int $J$ Health Care Qual Assur. 29(3): 300-23. doi 10.1108/IJHCQA-05-2015-0069.

Reaves AC (2015). Work creativity as a dimension of job performance. FIU Electronic Theses and Dissertations. Pp:92-98. Retrieved from https://core.ac.uk/download/pdf/46949766.pdf

Sarwar A (2014). Healthcare services quality in malaysian private hospitals: A qualitative study. International Journal of Hospital Research. 3(3): 103112. Retrieved from https://pdfs.semanticscholar.org/4bfe/c6584ede8a3 c7e09163675831cc7fbdd4009.pdf

Shaw C (2003). How can hospital performance be? measured and monitored? The Regional Office for Europe of the World Health Organization. Kopenhagen.

Sisyani, Firman P, Mariska U (2016). Perbedaan kualitas pelayanan pada sistem pembayaran INA-CBGs dengan fee for service di RS PKU Muhammadiyah Bantul (Difference in service quality Sis-tem INA-CBGs payment with fee for service at PKU Muhammadiyah Hospital of Bantul). Jurnal Asosiasi Dosen Muhammadiyah Magister Administrasi Rumah Sakit. 2- 
The Journal of Health Policy and Management (2017), 2(1): 42-57

https://doi.org/10.26911/thejhpm.2017.02.01.04

(2). Retrieved from http://repository.umy.ac.id/handle/123456789/20646

Sunarto (2005). Pengaruh komunikasi dan motivasi kerja aparatur terhadap kualitas pelayanan sertifikat tanah. Jurnal Komunikasi, 9 (2). Retrieved from https://ejournal.unisba.ac.id/index.p$\mathrm{hp} /$ mediator/article/view/1124

Wagner C, Groene O, Dersarkissian M, Thompson CA, Klazinga NS, Arah OA, Suñol R (2014). The use of on-site visits to assess compliance and imple- mentation of quality management at hospital level. Int J Qual Health Care, 26(1): 27-35. doi 10.1093/intqhe/mzuo26

Yongyuth P, Wim VL (2006). Choosing between public and private or between hospital and primary care: Responsiveness, patient-centredness and prescribing patterns in outpatient consultations in Bangkok. Tropical Medicine and International Health. 11(1): 8189. 